\title{
Paradigmatic or Critical? Resilience as a New Turn in EU governance for the Neighbourhood \\ Elena Korosteleva
}

\section{Abstract}

Rising from the margins of EU aid documents, resilience became a centrepiece of the $2016 \mathrm{EU}$ Global Security Strategy, especially in relation to the neighbourhood. While new resilience-thinking may signify another paradigmatic shift in EU modus operandi, the question that emerges is whether it is critical enough to render EU governance a new turn, to make it sustainable? This article argues that in order for resilience-framed governance to become more effective, the EU needs not just engage with 'the local' by way of externally enabling their communal capacity. More crucially, the EU needs to understand resilience for what it is - a self-governing project - to allow 'the local' an opportunity to grow their own critical infrastructures and collective agency, in their pursuit of 'good life'. Is the EU ready for this new thinking, and not just rhetorically or even methodologically when creating new instruments and subjectivities? The bigger question is whether the EU is prepared to critically turn the corner of its neoliberal agenda to accommodate emergent collective rationalities of self-governance as a key to make its peace-building project more successful.

Key words: European Union, resilience-thinking, governance, self-governance, eastern neighbourhood

\section{From governance by prescription to governance through resilience?}

In June 2016 Federica Mogherini, the Higher Representative for Foreign Affairs and Security Policy, and the Vice-President of the European Commission, announced a new vision for the EU's Global Security Strategy (EEAS). It was launched in the aftermath of the UK's Brexit referendum, and in the midst of rising extreme-right populism across Europe, a continuing influx of refugees, and the unfolding humanitarian disasters across the neighbourhood. Against this gloomy backdrop, comes a new vision for the European Union's (EU) global action, reciting resilience no less than 41 times especially in application to the neighbourhood (Juncos 2016: 3). As a concept, it rose from the obscurity of EU and global donors' aid and development documents to become a new organising principle for EU external relations. For the first time, 'resilience', officially defined as 'the ability of state and societies to reform, thus withstanding and recovering from internal and external crises' (EEAS 2016:23), was made a centrepiece, and a 'leitmotif' (Wagner and Anholt 2016) of the EU Global Security Strategy (EUGSS). What does the EU hope to achieve by moving resilience to the centre-stage of its external governance strategy, especially in relation to the neighbourhood?

To date, the EU has undergone a series of reflective shifts to make its external governance more effective and sustainable. At the time of their issuance they were seen as profoundly paradigmatic beginning with the articulation of its proximity strategy (2003/4), its regionalisation strategy (2008/9), a differentiation strategy (2011) and lately, an association strategy (2014+) vis-à-vis the wider neighbourhood (Korosteleva 2018; Henökl 2018). And yet, while innovative in their outlook and methodologies, those shifts were not critical enough to foster traction and rejuvenate a failing, in Commission's own words (2015a), neighbourhood policy. By making resilience its Global Strategy's 'leitmotif' (Wagner and Anholt 2016), the EU aims to up its stakes in the neighbourhood once more, by way of making it, firstly, more interestdriven and pragmatic; and secondly, more responsive, and adaptable to partners' needs to enable them to cope better with challenges of growing complexity and 'predictable unpredictability' (EEAS 2016: 46). It also promises more 'local ownership', insisting that 'positive change can only be home-grown' (Ibid:27), and more 'bottom-up' engagement, 'encompassing all individuals and the whole of society' (Ibid:24).

While some of these priorities may already sound familiar, resilience as a strategy, as some scholars would argue, may indeed offer some innovative solutions to what seems to be a perpetual crisis of EU neo-liberal 
governance, essentially driven by the EU-centric vision of the world, ${ }^{1}$ especially in the neighbourhood. In particular, Wagner and Anholt insist that, owing to its 'constructive ambiguity', resilience may be just that 'perfect middle ground between over-ambitious liberal peace-building and the under-ambitious objective of stability' (2016:417). Whereas, decentring and the emphasis on local ownership, as Fisher Onar \& Nicolaidis (2013) contend, may solve the problem of 'the functionalist hubris and political myopia', which EU institutions were recently charged with, when projecting external governance (Lavenex 2016).

Yet, on the other hand, resilience is too often associated with the same parochial reproduction of the neo-liberal agenda, which, according to Corry (2014: 270), 'deprives societies of the capacity for collective oppositional agency' and invariably, would lead to resistance, as resilient subjects' response to the 'inherent frustrations and associated [neoliberal] governance dilemmas' (Bourbeau and Ryan 2017:2).

So, what should this 'resilience-thinking' be as a new EU governance regime, in order to critically turn the corner, and to offer more sustainable solutions to the EU external peace-building project? Could the focus on 'resilience' indeed give EU governance a new momentum owing to its ability to learn from failure (Chandler and Coaffee 2017) to cope better and differently in the face of adversary? Would defining and understanding 'resilience' be a sufficient condition to improve governance strategies? Or should we focus more on the hitherto understudied meaning of 'self-governance', and the role of 'the local' before trying to reconcile neo-liberal governance with the emergent self-governing collective subjectivities? How can resilience as a governing strategy - both conceptually and methodologically - become not just paradigmatic, but distinctly critical to offer a new turn in (EU) governance studies?

Although 'resilience' as a concept is not new; in practical terms, it still constitutes a relatively unchartered terrain, especially when it comes to 'self-governance'. It will doubtless involve some methodological pioneering on the part of the $\mathrm{EU}$, which at the same time, will be complicated by its own delimitations of the term: while innovative in script, they often fall short of allowing EU governance to devolve and be creative. ${ }^{2}$ Furthermore, it becomes doubly problematic when situated in the context of a largely confused resilience scholarship, which paradoxically, problematizes more the process of (liberal) 'governance' rather than that of 'the local', or how to nurture its 'sense of good life' to be resilient. The overarching problem is that very few studies to date, when involving 'resilience', have a full comprehension of what state or societal resilience is all about, and how we can and should work with it, including this author. If resilience is truly about empowering 'the local', and growing their existing and yet critical capacities (Lundborg and Vaughan-Williams 2011), to enable change would require a far more radical de-centring conceptually, from those who govern to those who are subjectivised by it, and not by way of creating compliant (liberal) subjects as Joseph argues (2016), but rather by way of empowering 'peoplehoods' (Sadiki 2016). Furthermore, resilience's multiple genealogies and its ontological learning (Bourbeau 2018) suggest that it may not at all be about its conceptual and methodological defining. Neither is it entirely about responsibilising and devolving the reigns of governance to new subjectivities, within and outside the EU, who are still anchored to the EU scripts of governing rules and performance evaluation (Kurki 2011). It may not even be about 'governing through' instead of 'governing over' the predisposed and enabled new circuits of power, as Chandler argues (2014), for it would still be heavily reliant on the initial, though now distant centres of power to shape and direction the outside. This is where the true puzzle of resilience comes into stark contrast to our own external (neoliberal) governance thinking, which even at a distance, in the form of governmentality, still involves EU norms transference and alignment.

\footnotetext{
${ }^{1}$ For more discussion on neo-liberal governance and its vulnerabilities see Reid, J. and Chandler, D. (2016) The Neoliberal Subject: Resilience, Adaptation and Vulnerability. London: Rowman and Littlefield.

2 This is particularly instructive, as section 2 of this article demonstrates when exploring the meaning of 'resilience strategy' for the EU: while there is an increasing emphasis on local ownership in the EU 'resilience paradigm', the former is delimited to approving the EU vision for transformation and change, rather than developing a truly autonomous and more sustainable local governance.
} 
Taking resilience seriously, as this paper contends, implicates a number of rational possibilities. Ontologically, there should not necessarily be one reading of resilience that would aim to offer a 'one-fitall' vision of its genealogy and its future foresight: resilience may have multiple meanings (Bourbeau 2018; Reid and Chandler 2016), which should be engaged with, to offer resilience a chance to realise its rich potential, extending beyond the current neo-liberal settings.

Furthermore, methodologically, resilience does not simply imply a shift of 'responsibility on to individuals and communities', as Joseph would argue (2016:389). Rather, it should be about understanding 'the other' for what they are - even if they emerge as opposing collective agencies (Corry 2014) - to enable them to turn their existing capacities into critical infrastructures to necessitate change, from within, and make it sustainable. This, however, is different from identifying solutions from a list of prescriptive and reflective measures, or only investing in 'like-minded countries' and 'cooperative regional orders' as the EUGSS suggests (EEAS 2016: 8;10).

Most importantly, conceptually, resilience requires a radical rethink - and not as an externalising governing strategy, but more so, in terms of its actual value - as 'the local', self-organising practice of collective agency in search for a sense of 'good life'. It should involve re-discovering of 'self-governance' - and not necessarily as a 'conduct of conducts' (Foucault 2007), but rather, going beyond governmentality, to conceive of a gently guided self-organisation predicated on a deep sense of 'the peoplehood' (Sadiki 2017),community and 'agaciro' - the meaning of good life (Rutazibwa 2014), which are distinctly different from externalised governance. Perhaps, as Schmidt (2015) contends, it really needs a leap to imagine a post-neo-liberal world, of coordinated self-governance, premised on 'the home-grown local' and 'the everyday'. Is the EU ready to undertake this leap into the unknown and less governable tomorrow, even if its current resilience-infused discourse points in that direction?

This paper sets to unpack these and other questions about, first, resilience as a governance strategy, to see what current limitations of applying 'resilience' by the EU (section 2) and how they could be overcome to enable the EU to critically turn the corner, for more sustainable relations with the outside ontologically, methodologically and conceptually (section 3). What this paper will not do is to claim to offer definitive answers: instead it intends to problematize resilience as a theory of self-governance, which would hopefully make future discussions more purposeful, especially when it comes to reconciling external and self-governing projects. In what follows next, the first section will explore the genealogy of resilience and its ontological meanings to establish what is still potentially 'unsaid' about the concept, and its delimitations. In the second section, resilience will be examined methodologically, in terms of how the EU sees its application to practice. This will be situated in the context of the EU's previous paradigmatic shifts vis-à-vis the neighbourhood, to help understand where its true potential may be. Finally, conceptually, the paper will seek to explore the role and the place for 'the local' and 'the peoplehood' in the context of new resilience-thinking, to see if EU governance could critically turn the corner, towards more sustainable governing regime of the outside.

\section{Resilience's many ontological meanings: problematising the unsaid}

It is paradoxical that for a concept that has been in use by different strands of natural, environmental, social and political sciences, there is still little known about how it really works, and how and whether we ought to extend its utility from an individual to the level of states and societies, as part of the governance framing. As Bourbeau argues (2013:3), 'there is very little coherence and consensus as to the nature and substance of resilience. The term is employed but rarely unpacked, let alone theoretically analysed'. Resilience, as a concept, cuts across many disciplines - from ecology, psychology, computer sciences, to organisational and management studies, and now political studies and international relations - and noticeably, has relevance for many, conveying a strong narrative of the Self - individual and collective in their struggle for survival, self-esteem and self-reliance. As Bourbeau contends further, 'resilience has been identified as one of the most important and challenging concepts' (Ibid:4). And yet, there is still much unsaid about it, making it a potentially contentious concept for practical use, let alone as a 
'leitmotif' of EU Global Strategy (Wagner and Anholt 2016). How is it defined, what are its genealogical pathways, and should we strive to bring multiple definitions to a common denominator?

In his insightful article (2018), Bourbeau makes a strong and convincing claim against a single genealogy of resilience, believing that its pathways should be more inclusive, non-linear and not restrictive to any ideological context. Instructively, in response to a strong statement by Walker and Cooper (2011:144, in Bourbeau:3), implicating that 'the success of [resilience] in colonizing multiple arenas of governance is due to its intuitive ideological fit with a neoliberal philosophy of complex adaptive systems', Bourbeau purports that this singular interpretation is potentially detrimental to the conceptual richness and practical usefulness of the concept itself, especially in the context of governance. He urges to adopt a multiple genealogy of the term, which would have several important implications. First, it would open up space for 'debates on the strength, benefit, limits and weaknesses' of applying the concept to world governance, which is currently amiss. Second, it would also, while acknowledging the validity of relationship between 'resilience and neoliberalism', would put the concept into 'a broader and richer context so that the literature does not develop on the assumption that resilience is only a by-product of neoliberalism' (2018:15). Finally, it would permit the emergence of 'analytical frameworks capable of incorporating the multiple and multifaceted expressions of resilience manifest in our ..social world' (Ibid).

Taking Bourbeau's argument as an important departure point, this paper would insist on retaining resilience's multiple meanings - ranging from the notions of copying, 'bouncing back', to 'bending but not breaking' in the face of adversary - precisely for the purpose of inviting further discussion of its properties, positive and negative, to fully understand how the inner dynamics of the Self work for the purpose of survival and transformation. In the conceptual section, this paper would condense the multiple meanings of resilience to the notion of self-organisation of individuals to become part of a collective and sustainable agency, both domestically and externally, precisely to consider strategies for transformation in the context of external governance.

To continue in relation to its multiple meanings, resilience as it happens, is not at all uncontroversial or uniformly conducive to producing compliant subjectivities in the process of externalising one's governance.

A large strand of scholarship highlights human 'adaptability' - as the ability to bounce back - as a defining feature of human resilience. This goes back to the Latin origin of the word itself 'resilire', 'meaning 'to adjust easily to misfortune, adversity, unease, conflict, failure or change' (Bourbeau 2018). In social terms (Fleming and Ledogar 2008), this however, also implicates human ability to adapt to various regimes of governance (including of disciplining nature), in a struggle to survive and achieve stability. Under these headings many regimes in the neighbourhood, could be argued, exemplify an envious degree of resilience - Syria or Iraq are perhaps the most extreme cases here - in which individuals display a remarkable ability to adapt to the direst circumstances of watching their lives destroyed and yet staying put to survive. Less obvious and yet rather striking examples of adaptability include many post-communist regimes in the eastern region, where public appreciation of stability associated with political predictability, controlled environment and basic satisfaction of human needs, runs counter to the western claims for democracy, contestation and freedom. In these countries (e.g. Belarus is a case in point), the most oft-cited reference is 'as long as there is no war', people who had endured hardship and atrocities in previous wars and pass this legacy to future generations, become almost resistant to change, and negatively resilient in the face of any power deformation or rupture, naturally valuing stability and strong rule over the uncertainty of democratic governance. This complex social adaptability keeps many authoritarian regimes ${ }^{3}$ alive and

\footnotetext{
${ }^{3}$ Discussion of resilience in the context of authoritarian or non-democratic regimes is particularly important, because resilience, as a theory of self-governance, is focused on capacity-building of the existing critical infrastructures. Their identification and differentiation from the structures that support and reproduce nondemocratic regimes would be critical for societal and state resilience-building. This discussion however goes beyond the scope of this article, and will be developed elsewhere.
} 
functioning, simply because people have adapted their ways to survive the punitive nature of these regimes, and given their predictability, even to use regimes' inner workings to their advantage (hence corruption is so ingrained in the region as a paradoxical manifestation of societal resilience).

Ability to adapt and survive under whatever circumstances also breeds undesirability of change, and conformity. As Bourbeau aptly puts it: 'Resilience is not always a desirable feature of social, political or economic life. Being resilient might in fact mean being an obstacle to positive change in some cases.' (2013:8). Conformity, on the other hand, reinforces the existing order of things, effectively censoring dissent and bringing the abnormal in line with the normal, which in Foucault's terms (2007), leads to normation - observance of the prevalent norms, making existing regimes endue. For Zebrowski, conformity with social norms is the only norm that stands during disasters: in the face of adversary, they are 'far from breaking down', and will 'continue to govern behaviour' when all other 'dispositifs' of governance fail. Conformity, or adherence to the established norms, requires careful political engineering. This infers that 'the appearance of 'resilient populations' is [actually] an effect, rather the cause, of a broader restructuring of rationalities and practices comprising liberal governance' (2013:160); reifying resilience as an object of governance, rather a given. Zebrowski contends that for conformity to occur and for 'resilient populations' to emerge, 'a particular enframing of life, forged and sustained through the repeated exercise of governmental practices' is needed (Ibid:161). Instilling conformity in populations reduces the need for direct governance, thus leading to a form of neoliberal governmentality of managing the conduct of conduct, from a distance (Foucault 2007). He exemplified its utility on the notion of 'panic' during disasters, demonstrating that 'resilient populations' - those who display conformity with prevalent social norms - tend to recover quicker in the face of adversary, for they strongly rely on 'rules of the game' when given sufficient information for action.

Building resilience, therefore, is not simply about 'going back to the problem', as Chandler (2015) originally insisted, by way of removing institutional obstacles to ensure recovery. Crucially, it is about understanding the intricacies and implications of unleashing other properties of resilience - adaptability, conformity and undesirability of change. Resilience governance, when applied to social interactions on the level of states, opens up the whole Pandora box of difficult issues pertaining to power and selfgovernance. Biermann et al. for example, observe that resilience is often criticised for being apolitical and privileging 'social structures serving to reproduce the status quo'. Operating in the domain of power relations, resilience also provokes 'questions about resilience of what and for whom', especially when naturally assuming that 'a resilient system is a desirable one'. These 'assumptions' however 'can lead to failure to recognise issues of power, justice, and equality in discussions of resilience' (2015:3). Furthermore, being indiscriminate in its application, resilience governance 'may even allow hegemonic values and discourses to be actively perpetuated' (Ibid) thus admittedly embedding and maintaining the asymmetry of power in the subject-object relations with a recipient. This certainly raises some fundamental questions, as to 'what needs to be kept resilient, to what and for whom' (emphasis original); as well as 'how to advance discussion about political subjectivities, radical change or alternative democratic modes' (Ibid:13) which are currently amiss or not critically spoken of in the wider resilience literature. Instead the latter currently relies on a 'highly scientised and prescriptive' manner of executing liberal governance of 'known knowns' (Biermann et al 2013:13) over the outside, as our study of EU governance regime in the next section will expose.

In a similar vein, under resilience governance, as Mavelli argues (2016), power hierarchies are particularly pronounced often reinforcing injustice, and stigmatising 'inferior species' if they are perceived to be a threat to the system's survival. They could even be punitive, through specific governance measures, to punish those who, through descent, come to challenge the status quo. Mavelli pungently demonstrated this 'dark side' of resilience governance on the EU behaviour towards the Greek crisis. He contended that if anything, EU disciplinary governance caused a flip-over effect by making 'the Greeks more resilient' when going through the bailout process; and the Europeans - 'less resilient' as being 'biopolitically sheltered from the potential failures of their own banks' (2016:20). Crucial to his analysis, however, was 
the exposure of the centrality of neoliberal power and its hegemony (by the most powerful European states and Germany in particular), which instead of protecting all parties from the economic shock of the Greek crisis, chose to punish the weakest by 'transferring the crisis onto less wealthy' and protecting 'powerful countries through biopolitical racism in order to advance the dynamics of neoliberal exploitation' (Ibid:20).

This brings us to the most striking 'hidden' element of resilience governance - compliance as a counterintuitive effect of building resilience and individual self-reliance, in a neo-liberal context. Notably, Joseph argues (2013:45) that while putting an emphasis on the individual by way of micro-focusing on 'the everyday' and 'the local', resilience governance contentiously does not seek to empower autonomy, and comes at odds with the notion of 'self-governance', an admitted goal of societal resilience. Notably, Joseph contends that 'autonomy appears as a problem which requires management... The autonomy of the individual is a problem for development'. He insists that, in a neo-liberal tradition, 'individual freedom is something socially constructed within complex adaptive systems' (Ibid). Hence, resilience building, from this perspective, is not and has never been, about empowering an individual, or a societal ability to bounce back in the face of complexity, but rather about constructing power dependencies to render 'conduct of the conduct' perpetual, and locked into a cycle of power (re)production in the form of coordinated 'self-governance'. In this vein, Joseph concludes, resilience governance 'might be actually more effective in securing compliance to international norms, forcing states and local populations to adapt their behaviour in the face of problems that the international community either cannot, or does not, want to deal with itself' (2016:373). According to this (neo-liberal) thinking, engendering 'selfgovernance' through resilience is an illusion, or an ideal, which realisation is as undesirable as an investment into one's capability to challenge an existing order. In short, not only are self-governance and autonomy treated as needed to lock subjectivities into a continuing mode of social power re-production; they also come in stuck contradiction with, and even denial of the very notion of active opposing agency (Corry 2014) and 'self-organisation' as desirable for the sustainability of the liberal internationalist world order.

To conclude, we ought to keep, at least for now, the many meanings of resilience open for discussion, in order to fully understand its conceptual and methodological delimitations, to free it from any ideological bias, and to search for more cooperative and sustainable forms of governance, if self-governance were to become the premise of a new order. The next section will examine how resilience is being understood by the EU, and what methodologies are being deployed to make EU governance more effective.

\section{The Methodological Underpinnings of Resilience in EU Governance}

For a relatively new concept, 'resilience' has already made quite an impact in EU governance-thinking.

Resilience firmly entered the EU agenda in 2012, being part of the EU re-thinking its humanitarian and development policies (Commission 2012). It was borrowed from ecological/environmental studies to help understand 'how systems can cope with, and develop from, disturbances' (Bourbeau 2013:7). At the time resilience began to be seen not just simply as a response to coping with disasters (especially of humanitarian nature), but also as a long-term systemic solution 'to tackle the root causes' of these crises, as part of a new development agenda. In governance terms, it allowed the EU to intervene and coordinate external humanitarian/development agendas, to offer solutions which then could be simply 'embedded in national policies and planning' (Ibid:2). This thinking gradually allowed the EU to develop the so called 'resilience paradigm' inclusive of the EU expanding portfolio of 'know-how' technologies, good practice initiatives (e.g. SHARE; AGIR in Commission 2012) and methodologies of monitoring and evaluation. Resilience as a term was defined as 'the ability of an [entity] to withstand, to adapt, and to quickly recover from stresses and shocks' (Ibid: 5). Most crucially, it relied on two specific dimensions: one was the 'inherent strength of an entity ... to better resist stress and shock', and two, was the 'capacity of this entity to bounce back rapidly from the impact' (Ibid:5). The Commission argued that increasing resilience could be achieved 'either by enhancing the entity's strength, or by reducing the intensity of the impact, or both' 
(Ibid). The EU firmly believed in its own ability to control, manage and where necessary prevent disasters from happening - a type of governance regime, that Chandler (2014:50) would describe as 'modernist' or 'liberal', which would operate through the 'known knowns' drawing on a 'linear and universal assumption of the progressive accumulation of knowledge of laws and regularities' (2014:50) which then could be transferred and embedded into partners' development programmes.

Importantly, the EU-coined resilience paradigm was predicated on three core operational principles, which continue to shape EU governance-thinking today. First, in light of its expanding knowledge and techniques, even with the increasing uncontrollability of the outside, the EU believes it is better positioned to advise states and individuals on best-fitting 'governance structures', and a 'stakeholders' capacity needs' to enhance their preparedness and adaptability, which would need to be embedded and strengthened at the local and national levels (Commission 2012: 9). Second, the EU strongly emphasises 'local ownership' of these external technologies-turned-capabilities, to ensure partners' commitment and openness to a long process of resilience-building: 'resilience can only be built bottom-up', and 'the starting point for the EU approach is .... firm recognition of the leading role of partner countries' (Commission 2012: 11). Finally, the EU importantly insists on applying its own 'sound methodologies' of monitoring and evaluation to improve response and future governance. Notably, 'to ensure effectiveness, the EU will put in place a framework for measuring the impact and results of its support for resilience', to include EU-funded programmes, a common operational assessment prepared by experienced humanitarian and development actors; and 'Implementation Plans', 'so as to ensure maximum complementarity' and 'flexibility in the programme design'. Furthermore, the Commission shall 'review regularly the progress made on the resilience agenda, looking in particular at programming, methodologies and results' (Ibid:12), to lock partners into the emergent circle of governance. In short, it is instructive to see how emblematically opposing the EU understanding of resilience - as a packaged intervention inclusive of modular governing strategies, monitoring/evaluation methodologies and 'local ownership' deployed to legitimise this intervention - is to the multiple meanings of resilience as a concept, which centres around 'self-governance' and 'the local'.

The next few years saw some further programming of the EU resilience principles into the wider areas of development/humanitarian policies, along with a parallel expansion of the 'security-development nexus' (Ibid:5), which subsequently offered propitious grounds for extending resilience into the strategic security and foreign policy domains. In particular, in 2013 the Commission introduced an 'Action Plan for Resilience in Crisis Prone Countries', which, while underscoring the 'country-owned and -led' nature of resilience, and a 'people-centred approach', contributed to further testing and expansion of provisions for the EU resilience paradigm:

- 'EU support to the development and implementation of national resilience approaches [should be] integrated in National Development Plans'. The intention is to develop 'shared assessments, strategies and implementation plans to build resilience' and 'the necessary body of evidence for further action' (2013: 4). 'The Action Plan recognises that the EU is already incorporating resilience into many national programmes', and 'EU interventions ... already have resilience as a core policy priority' (Ibid) for the recipient countries

- 'A common understanding of resilience objectives is required by government and international partners... The EU Roadmaps of engagement represent an opportunity to do so at a country level' (Ibid:5)

- 'Methodologies and tools to support resilience [should include] EU procedures and mechanisms, involving the Commission, the EEAS, the EU Delegations, as well as all relevant stakeholders to monitor, build the evidence base and learn from best practice' (Ibid).

- 'Guidance on the implementation of the EU's approach to resilience will be prepared and trainings organised for all partners' (Ibid:6). 
These provisions subsequently culminated in the formulation of a logframe of management arrangements which allowed the EU to master its resilience-building approach, and make it transferrable. They included a template of implementation measures, comprising a set of actions, accompanying activities, time-frame, and anticipated outputs. In 2014 this resilience development strategy was further consolidated into a 'Compendium' (Commission 2014a) - a comprehensive 116 page-long good practice guide with case studies and planning tools to assist partners in developing a coherent agenda for their resilience objectives; and a 'Resilience Marker' (Commission 2014b), offering a manual to partner countries as to how to build their resilience, with EU support.

With gradual expansion of the 'security-development nexus', by 2015 resilience moved to the EU foreign policy domain, specifically focusing on the neighbourhood. As Juncos affirms, 'the revised ENP strategy adopted at the end of $\mathbf{2 0 1 5}$ was one of the first documents to introduce resilience-building as a foreign policy goal' (2016:3). As before, the document effectively rehearsed the EU's resilience paradigm, setting out measures for the neighbourhood, 'to offer ways to strengthen the resilience of the EU's partners in the face of external pressures and their ability to make their own sovereign choices' (Commission 2015b:2).

By 2016, resilience made it into the EUGSS to define the EU modus operandi across the globe. This time, however, the resilience narrative has received a rather different framing: it became less assertive about the EU's ability to regulate and control the outside, and instead it strongly emphasised the world's growing complexity and the need to become and make partners, better prepared for no longer controllable eventualities. In place of the familiar mantra of 'knowing the knowns' in how to better placate emergencies, new resilience-thinking chose to paint a picture of global 'existential crises' (EEAS 2016:7) and 'predictable unpredictability' (Ibid: 46), shifting the focus on to 'the unknowns', and how to learn to correct the gaps in knowledge where possible (Chandler 2014). Furthermore, in the context of the EUGSS' claim of the growing contestation of liberal order whereby 'the purpose, even existence, of our Union is being questioned' (Ibid:3), resilience, in the language of the EU, seems to have shifted, to firmly associate with protecting the neoliberal agenda and its subjects, thus becoming to be seen not just as a by-product of liberalism, but essentially its tool.

So, what are the implications of this resilience-thinking as part of extending EU governance regime onto the neighbourhood?

As said in the introduction, the EU has been reflective of its limited governance effect in the neighbourhood, trying to address the challenge via new or improved methodologies of engagement, described here as paradigmatic shifts. In particular, the first paradigmatic shift in EU external governance was linked to the launch of the European Neighbourhood Policy (ENP) in 2003/4, signifying a move away from the EU enlargement modus operandi to a partnership-building regime (Korosteleva 2012). While novel in rhetoric, in practice it continued to rely on a lighter version of the enlargement modality (Kelley 2006), involving direct transference of the EU 'know-how' (acquis communautaire) and conditionality. This approach was often aptly referred to as EU 'inside-out' external governance (Lavenex 2004) to underscore the prevalent at the time episteme of the governing process - the EU rationality of 'knowing the knowns' (Chandler 2014) - that is, having sufficient instrumental knowledge, progressively accumulated through the enlargement process in Europe, to effectively drive change in the neighbourhood. The prevalent operational features of this type of (liberal) governance regime, included:

- a hierarchical mode of coordination favouring executive bias and bilateral communication with national governments

- a binary way of inculcating EU normative practices: 'take-it' or 'leave-it' approach without accounting for regional socio-cultural differences, and

- a prescriptive instrumental approach to reforms involving conditionality and, in case of noncompliance, disciplinary actions (sanctions, naming-and-shaming and other means of economic/political statecraft). 
This type of regime, embodying EU disciplinary governance, had a limited effect on the neighbourhood, especially in terms of generating partners' commitment and 'local ownership' of the proposed reforms. Conversely, it caused a discomforting sense of inferiority among the neighbours, their disenfranchisement with power asymmetry vis-à-vis the EU (Kelley 2006; Raik 2006; Wolczuk 2009).

The second paradigmatic shift in EU governance took place in 2008/9 by introducing the policy's regionalisation, resulting in the launch of two complementary umbrella initiatives - the Union for the Mediterranean (UfM) and the Eastern Partnership Initiatives (EaP) respectively. The EU innovated on a range of methodologies, endeavouring to recalibrate the meaning of 'local ownership', and to give its approach more inclusivity and traction. A dual-track approach was introduced to diversify EU channels of engagement and to target other than government actors (subjectivities) to snowball reforms in the recipient countries. This tool paved the way to the rise of civil society as an influential agency for promoting change in the region.

In 2011 this approach witnessed further innovations spanning from new forms of contractual agreements - Association Agreements (AAs), Mobility partnerships and Deep Comprehensive Free Trade agreements (DCFTAs) - to new means of monitoring and control - from roadmaps, association agendas and logframes for key deliverables. The refined governance strategy also yielded new policy actors (subjectivities) engaging all levels of society from grass-root NGOs and local authorities to regional and national level government agents and businesses. This approach did not only consolidate the 'know-how' of the EU governance framework to date, building on its progress and policy failure, it also brought together an incredible machinery of EU tools and instruments - in a 'more for more' formula - aiming to target 'the local', 'from a distance' (as governmentality in a Foucauldian sense), in a less disciplinary, and a more bottom-up manner (Korosteleva 2014 et al). In summation, the main features of the new EU governance regime included:

- control from a distance, and only of the pertinent, allowing for more local ownership, agendainput and tailored solutions;

- a complex matrix of "enablement" premised on voluntary engagement and rational freedom of choice aiming to lock ENP countries in the perpetual mode of 'more for more cooperation';

- engagement of all levels of society: from civil society, business and education actors, to local/regional authorities, national governments, parliaments, and media representatives, thus generating an all-inclusive grounds for mutual learning and socialisation into European norms and standards;

- 'optimal (rather than binary) space' between 'the permitted' and 'the prohibited', allowing neighbours to approximate rather than fully replicate European norms and values, thus accounting for and preserving their 'cultural space' as well;

- development of a dual track of engagement: making the bilateral track more technocratic (e.g. roadmaps) and the multilateral track more "political" to generate a sense of community and this way, re-engineer public behaviour in the neighbourhood.

This regime of EU governance-thinking closely resonates with a 'neo-liberal' turn in governance, as the one that reflectively tries to identify gaps in knowledge and reasons for resistance (knowing 'the unknowns'), and methodologically tackle them via new instruments (budgets, subjectivities, new power circuits, formats of contractual relations, benchmarks, roadmaps etc.), to improve performance on deliverables. And yet, this revised governance strategy came to a grinding halt by 2014 , and ensuing a drawn-out civil war in Ukraine, diplomatic impasse with Russia, and a highly unsettled environment for pursuing EU governance across the region.

The above paradigmatic shifts in governance, while underlying the EU's responsive mode of engagement, also vividly demonstrate the EU's struggle to find more traction for extending and legitimising its governance over the neighbourhood: neither the macro-level disciplinary governance nor a more tailored governmentality approach made it in any way more sustainable, let alone effective (Korosteleva et al 
2014). Could a new focus on resilience in 2016 help remedy the continued failings of EU governance especially in terms of the EU's better understanding of how to engage with a contested region, torn by civil war, claims for secession, corruption, government privatisation and envious autocratic stability? After all, if the utility of resilience, as Joseph argues (2016), is to help frame a suitable mode of governance learning from its own failures, then the question writ large here is if 'resilience' would be a critical enough narrative to make a difference, for a more effective and sustainable EU approach towards the neighbourhood.

On the one hand, even the mere articulation of a more pragmatic policy approach, seems to have ensued a fledgling dialogue and negotiations with more recalcitrant partners, like Belarus and Azerbaijan, who hitherto had been subject to the EU sanctions (Belarus), or limited engagement (Azerbaijan). The EU has now successfully pioneered a new Comprehensive and Enhanced Partnership Agreement (CEPA) with Armenia, which, while being committed to the Eurasian Economic Union, is still keen to continue pursuing a more tailored engagement with the EU (EEAS 2017).

On the other hand, much depends on a new format that a resilience-premised governance is likely to take. If it does choose to de-centre, to invest more in a critical capacity-building at the individual/societal level, then it needs to fundamentally re-think its learning about the outside, predicated more on a better understanding of self-governance, and a potentially opposing communal agency (Corry 2014). At the same time, does the EU, and/or the wider scholarship know enough about resilience as 'self-governance' to make the right call this time, to ensure a better EU response to the external challenges, especially in the neighbourhood? So far, judging by the EU's proposed practical measures to build resilience in the neighbourhood, as articulated in the Commission's 'Key deliverables' (2016), there is a strong feeling, that the EU resilience paradigm will be rehearsed again to lock partners in to the EU hubristic mode of governance, as before, associated with embedding 'governance infrastructures', and logframes for monitoring and evaluation, treading on 'self-governance' but not coming close enough to allow autonomy and self-organisation.

How should resilience be conceptualised to really help reset the EU governance approach to give external communities an opportunity to build their own existing capacities, and to empower their sustainable selforganisation? So far, the EU's use of resilience tells us more of an EU story of what resilience building should be all about, and how it could be assessed and evaluated to improve performance. We need to understand resilience for what it is, and how it is connected to 'the local' and the 'peoplehood', before conceiving of how it could make EU external governance more sustainable for the outside.

\section{Conceptualising resilience in 'the local': towards a new critical turn in governance}

For more cooperative and sustainable governance to occur, predicated on resilience-thinking, it would require, as Chandler contends (2014), embracing complexity in full, and with it, a recognition of the uncontrollability of the outside. This, however, is different to (neo)liberal thinking about complexity: Resilience-thinking instead requires a shift beyond instrumental governance operating in a 'world amenable to cause-and-effect understandings of policy-making' (Ibid:58), and relatedly, a rejection of the two core tenets of the EU Transition Paradigm - the management and assessment of resilience-building inside-out fomenting dependable subjectivities. This means moving beyond the certainties of (neo)liberal order, with its 'known knowns' rationalities of regulatory policies and interventionist practices. It also infers contesting a neo-liberal mode of governance which opens up to accepting complexity but still operates from a position of certainty about the 'known unknowns', to be ready to 'intervene instrumentally in the sphere of complex social interactions' (Ibid: 54), on self-reflection, and to remove 'institutional blockages... as unintended outcomes of policy-making' (Ibid:56). Resilience, for Chandler, is definitely a leap beyond neoliberalism, whereby zooming onto 'the everyday', as it naturally does, is 'not about governing from the top-down or the bottom-up but about ... the existing embedded and relational capacities of ordinary people. It is these capacities that are perceived to be bypassed or muted by 
instrumentalised neoliberal interventions in social sphere' (Chandler 2014:60). This type of governance infers working through, or more pertinently, with society: 'through recognising the capacities and capabilities that already exist and could be encouraged (Ibid:61). It is simply about an ontological understanding of our natural abilities to cooperate with each other and construct communities of shared interest. In this this sense, governance based on resilience, needs to be reframed 'in order to recognise the creative and self-ordering power of life itself' (Ibid:62).

This, however, constitutes a radical departure from an illusory sense of autonomy of the neo-liberal world for which resilience, as Joseph posits (2016), is to socially construct reliable subjectivities, to conduct people's lives in their strife to survive and adapt in the face of adversity. This suggests that neoliberalism may have exhausted itself: 'turned into a governance programme, [it] seems inherently self-consuming' (Schmidt 2015:414), and requires a pragmatic solution - from decision-making to self-cultivation - to allow resilience to achieve its true potential, which is no longer delimited by its 'dark side' demanding compliance, conformity and undesirability of change. A pragmatic solution would seek to move beyond instrumental rationalities of neoliberalism, to imagine a self-organised collectivity, whose resilience is instead predicated on a growing sense of the self, its creative capabilities and critical infrastructures, to engender longevity and cooperative sustainability in a complex and uncontrollable environment.

At the same time, how to make this leap, and with it, to render resilience a better/richer rationality for more effective governance framing, is still an open question. Some (Kaufmann 2013) might argue that new and more creative methodologies are needed to ensure people's strife for self-reliant and sustainable societies gently coordinated by a supportive inside-outside relationship. Others (Chandler 2015; Korosteleva 2017) would say that the resilience potential for more effective governance lies with the people, and 'the everyday', which we are yet to discover through the process of othering, where the self and the other are understood not in opposition and not even in juxtaposition to one another, but rather as a nexus of learning and self-development. This understanding is not necessarily to be attained via new knowledge and the expansion of our epistemological horizons, but rather ontologically - through accepting other-ness as a way to relate the self to the outside in order to understand their life, needs and desires, and treating them as what they are, and want to be, rather than should be, in accordance to the self' thinking.

This new de-centred thinking can be captured by a communal sense of 'good life', or the Arabic term 'alharak', referring, as Sadiki argues (2016:338) to the 'peoplehood' to encapsulate their vision for better life, essentially as 'people-driven ferment'. Rutazibwa (2014) takes it to a level further, by introducing and exploring the notion of 'agaciro', which implies people's 'understanding that [they] are the agents of [their] own change' (2014:5). In particular Rutazibwa argues that agaciro is a philosophy of life that draws on self-reliance and the inner knowledge of the people of what they are, and what they want to be, and could serve as a premise for resilience governance thinking. She contends further that 'agaciro' stands for self-knowledge as foundation for self-governance:

People know what is good for them. We must endeavour to show it. We must be seen to be doing things that prove that. So Agaciro is simply central to everything we are doing for our development, that pride, that belief in ourselves, that being who we are and who we should be, and trying to be the best we can be (2014:6)

Agaciro, as the everyday and the local, relies on three essential elements: it is outward underscoring autonomy and sovereignty; it is inward legitimising expectations of a new social contract, and it is individual encapsulating a newly found self-worth identity linked to pride in the future that is being built today (Ibid:7). In many ways, it encapsulates the best side of resilience allowing people to define what they are and where they want to be, and travel to that destination, if necessary with the support of others. This kind of resilience does not generate conformity and compliance with the norms and rules of the external authority in the pursuit of their ideals; rather it encourages diversity and self-cultivation through cooperation. It does it through a particular type of othering that locks in the self and the other, in a 
reciprocal partnership-based learning that cannot be achieved through external strategy papers, progress reports and logframes to manage and evaluate partners' performance against external identified benchmarks, as neoliberal thinking would naturally assume. This kind of othering comes with a particular ontological type of learning that draws on a relational value of the self and the other in their connected development, whereby 'the value of the self is determined through its external environment' (Edkins 1999: 24), thus reversing the logic of governance onto itself. From this perspective, as Chandler argues (2014:57) 'the policy failure is, in fact "not a failure of policy", but a learning opportunity... it is governance failure, which is the failure to reflexively learn from complex life the need to overcome reductionist understandings'.

While this type of resilience thinking is profoundly relevant to the increasing complexity of the outside, it still requires more consideration of its practicalities - of how to realise the resilience potential in practice. Can we rely on the everyday, the local and the peoplehood, to know exactly what their challenges are, and more importantly, how to overcome them, in becoming what they want to be - in their agaciro?

This is still an open-ended question. Intuitively, as Chandler points out (2015:38), resilience governance presumes a process of 'construction or recognition of "negotiated moral communities' capable of selforganising in relation to the shared world'. At the same time, how are we to build these 'negotiated moral communities', and how different are they from the real-life communities which might endue daily hardship, and regime's naked brutality, as the thwarted March for Freedom in Belarus on 25 March 2017 attested to, and continue living through, for the sake of survival. How do we achieve the kind of resilience that would unlock critical infrastructures to nurture good governance from within? What kind of governance would it require to avoid the entrappings of compliance and dependency?

Kauffmann (2013) suggests to place more emphasis on the study of self-organisation, as part of the wider network system of governance. She argues that self-organised communities, while relying on external support, have an inner sense of direction, a notion of 'self-referentiality' (2013:60) that foment system's reorganisation without recourse to the resources of the outside. This kind of governance might be best described as 'guided self-organisation', which relies on a networked system of shared interests and rules, where the whole renders support to the local, and the local changes the whole through creative selforganisational performance (Ibid:68). In this context, resilience of the peoplehood, as Chandler argues, 'removes the external intervener from external intervention and with this makes local capacities, practices, and understandings the means and the ends of intervention' (2014:48) - in self-reliance and as part of the whole.

\section{Conclusion}

This article has critically explored the notion of resilience as the emergent EU governance regime. While still relatively new to the domain of international relations, resilience as a concept has already made quite a career, recently claiming its place in the EU global security strategy, in defining EU relations with the outside, and the EU neighbourhood in particular.

Emerging from the EU humanitarian and development agendas, by the early 2010s resilience found its practical enframing in the so-called Resilience Paradigm, as aptly coined by the Commission. Its application was premised on the assemblage of three core governing principles, including (i) the knowledge of best-suited 'governing strategies' ('knowing the knowns/or unknowns'); (ii) EU management and evaluation procedures for implementation and control; and (iii) a demand for local ownership, to ensure recipients' commitment and endurance. By 2016 resilience took the centre-stage of the EU Global Security Strategy, especially in relations with the wider and very much troubled neighbourhood, seeking to inject new dynamics in the hitherto failing EU modus operandi for partners' greater commitment and change. 
This paper has argued that in order to make resilience a tangible tool for enabling the EU to turn the corner for more effective and sustainable governance, we need to give it a far more careful consideration - ontologically, methodologically and conceptually - than it is presently being afforded.

In particular, ontologically, we should re-engage with the many meanings of resilience, to uncover and understand its multiple genealogies, in order to better grasp its inner and often controversial dynamics, and to give it a chance to realise its rich and yet understudied potential. This may mean even extending its etymology beyond the neo-liberal settings of governance fallaciously premised on "knowing the knowns' or even 'the unknowns' when dealing with complexity.

It also implies changing EU external governance approach, both methodologically and especially conceptually, to ensure it is not just simply about reproducing and enforcing compliance and 'the illusion of autonomy', that makes it a necessary element of 'conducting the conduct' of the external milieu, in the name of a liberal-internationalist peace-building project.

Quite the opposite, as this article has argued: resilience, if taken seriously, requires an urgent rethink of its actual value - namely, as a concept and practice of 'self-governance', putting a self-organising principle of a collective (and invariably) autonomous agency in search for its own sense of 'good life', at the heart of their modus operandi. This would entail new ways of not just thinking about, but also invariably adapting 'external governance' to the needs of self-governance, as enabling 'the peoplehood', and 'the local', to make global governance more sustainable.

\section{References}

Biermann, M., Hillmer-Pegram, K., Knapp, C.N. and Hum, R.E. (2016) 'Approaching a Critical Turn? A Content Analysis of the Politics of Resilience in Key Bodies of Resilience Literature', Resilience: International Policies, Practices and Discourses, 4(2): 59-78

Bourbeau, P. (2013) 'Resiliencism: Premises and Promises in Securitisation Research', Resilience: International Policies, Practices and Discourses, 1(1): 3-17

Bourbeau, P. (2018) 'A Genealogy of Resilience in World Politics', International Political Sociology, 12(1): $1-20$

Bourbeau, P. and Ryan, C. (2017) 'Resilience, Resistance, Infrapolitics and Enmeshment', European Journal of International Relations, DOI: 10.1177/1354066117692031

Chandler, D. (2014) 'Beyond Neoliberalism: Resilience, the New Art of Governing Complexity', Resilience: International Policies, Practices and Discourses, 2(1):47-63

Chandler, D. (2015) 'Resilience and the "Everyday": Beyond the Paradox of "Liberal Peace"', Review of International Studies, 41:27-48

Chandler, D. and Coaffee, J. (eds., 2017) The Routledge Handbook of International Resilience. London: Routledge

Corry, O. (2014) 'From Defense to Resilience: Environmental Security beyond Neo-Liberalism', International Political Sociology 8:256-74

Edkins, J. (1999) Poststructuralism and International Relations: Bringing the Political Back In. London: Lynne Rienners Publishers

European Commission (2012) The EU Approach to Resilience: Learning from Food Security Crises. COM 586 final. Brussels, 3 October

European Commission (2013) Action Plan for Resilience in Crisis Prone Countries 2013-2020. SWD 227 final. Brussels, 19 June

European Commission (2014a) EU Resilience Compendium: Saving Lives and Livelihoods. Brussels, April. Available at http://ec.europa.eu/echo/files/policies/resilience/eu resilience compendium en.pdf

European Commission (2014b) Resilience Marker: a General Guide. Brussels, November

European Commission (2015a) Towards a New European Neighbourhood Policy. JOIN 6 final. Brussels, 4 March 
European Commission (2015b) Review of the European Neighbourhood Policy. JOIN 50 final. Brussels, 18 November

European Commission (2016) Eastern Partnership - Focusing on Key Priorities and Deliverables. SWD 467 final. Brussels 15 December

European External Action Service (EEAS, 2015) The European Union in a Changing Global Environment: a more connected, contested and complex world. Brussels, June. Available at http://eeas.europa.eu/archives/docs/docs/strategic review/eu-strategicreview executive summary en.pdf

European External Action Service (EEAS, 2016) Shared Vision, Common Action: A Stronger Europe. A Global Strategy for the EU's Foreign and Security Policy. Brussels, June. Available at http://eeas.europa.eu/archives/docs/top stories/pdf/eugs review web.pdf

European External Action Service (EEAS, 2017) EAP: Comprehensive and Enhanced Partnership Agreement between the European Union and Armenia (CEPA). Available at https://eeas.europa.eu/sites/eeas/files/eng_cepa_factsheet_armenia_digital.pdf

Fisher Onar, N. and Nicolaidis, K. (2013) 'The Decentering Agenda: Europe as a Post-Colonial Power', Conflict and Cooperation, Special Issue, 48(2):283-303

Fleming, J. and Ledogar, R. (2008) 'Resilience, an Evolving Concept: A Review of Literature Relevant to Aboriginal Research', Pimatisiwin, Summer 6(2): 7-23. Available at https://www.ncbi.nlm.nih.gov/pmc/articles/PMC2956753/

Foucault, M. (2007) Security, Territory, Population: Lectures at the College de France 1977-78 (ed. by M. Senellart; tr. by G. Burchell)

Henökl, T. (2018) 'The European Neighbourhood Policy and the CFSP/CSDP: from the European Security Strategy to Global Strategy', A. Marchetti, T. Demmelhuber, T., and Schumacher, T. (eds.) The Routledge Handbook on the European Neighbourhood Policy, Ch.46. London: Routledge

Joseph, J. (2013) 'Resilience as Embedded Neoliberalism: a Governmentality Approach', Resilience: International Policies, Practices and Discourses, 1(1): 38-52

Joseph, J. (2016) 'Governing Through Failure and Denial: The New Resilience Agenda', Millennium: Journal of International Studies, 44(3): 370-90

Juncos, A. (2017) 'Resilience as the new EU Foreign Policy Paradigm: a Pragmatic Turn?', European Security, 26(1): 1-18

Kaufmann, M. (2013) 'Emergent Self-Organisation in Emergencies: Resilience Rationalities in Interconnected Societies', Resilience: International Policies, Practices and Discourses, 1(1): 53-68

Kelley, J. (2006) 'New Wine in Old Wineskins: Promoting Political Reforms through the New ENP', Journal of Common Market Studies, 44(1): 29-55

Korosteleva, E. (2012) The European Union and Its Eastern Neighbours: Towards a More Ambitious Partnership? Abingdon: Routledge.

Korosteleva, E. (2017) 'The Eastern Partnership: Bringing the Political Back In', Special Issue, East European Politics, 33(3): $1-25$

Korosteleva, E. (2018) 'The Challenges of the Eastern Neighbourhood', in A. Marchetti, T. Demmelhuber, T., and Schumacher, T. (eds.) The Routledge Handbook on the European Neighbourhood Policy, Ch.15. London: Routledge

Korosteleva, E., M. Natorski and L. Simão (eds., 2014). EU policies in the Eastern neighbourhood: the practices perspective. Abingdon: Routledge

Kurki, M. (2011)'Governmentality and EU Democracy Promotion', International Political Sociology, 5: $349-66$

Lavenex, S. (2004) 'EU External Governance in "Wider Europe"', Journal of Public Policy, 11(4):680-700

Lavenex, S. (2016) 'On the Fringes of the European Peace Project: The Neighbourhood Policy's functionalist Hubris and Political Myopia', British Journal of Politics and International Relations, 1-16 DOI: 10.1177/1369148116685261

Lundborg, T., and Vaughan-Williams, N. (2011) 'Resilience, Critical Infrastructure, and Molecular Security: The Excess of "Life" in Biopolitics"', International Political Sociology, 5: 367-383 
Mavelli, L. (2016) 'Governing the Resilience of Neoliberalism through Biopolitics', European Journal of International Relations, 1-24, DOI: 10.1177/1354066116676321

Miller, P. and Rose, N. (2008) Governing the Present: Administering Economic, Social and Personal Life. Cambridge: Polity

Raik, K. (2006), 'The EU as a Regional Power: Extended Governance and Historical Responsibility', in H. Mayer and H. Vogt (eds.) A Responsible Europe? Ethical Foundations of EU External Affairs. Basingstoke: Palgrave Macmillan: 76-98

Rutazibwa, O. (2014) 'Studying Agaciro: Moving Beyond Wilsonian Interventionist Knowledge Production on Rwanda', Journal of Intervention and Statebuilding, 8(4): 291-302

Sadiki, L. (2016) 'The Arab Spring: The "People" in International Relations', in L. Fawcett (ed.) International Relations of the Middle East. Oxford University Press, Ch.15, pp. 325-55

Schmidt, J. (2015) 'Intuitively Neoliberal? Towards a critical understanding of Resilience Governance', European Journal of International Relations, 21(2): 402-26

Wagner, W. and Anholt, R. (2016) 'Resilience as the EU Global Strategy's New Leitmotif: Pragmatic, Problematic or Promising?', Contemporary Security Policy, 37(3): 414-430

Wolczuk, K. (2009) 'Implementation without Coordination: The Impact of the EU Conditionality on Ukraine under the European Neighbourhood Policy', Europe-Asia Studies, 61(2): 187-211

Zebrowski, C. (2013) 'The Nature of Resilience', Resilience: International Policies, Practices and Discourses, 1(3): 159-73

\section{Acknowledgements}

I wish to thank the anonymous referees, and the JIRD editors for their constructive feedback on the earlier versions of this paper.

\section{Funding}

This project was supported by the EU Horizon 2020 UPTAKE project [grant No 691818] and GCRF RCUK COMPASS project, 2017-21 (ES/PO10849/1)

Word count: 8152 excluding abstract, bibliography and acknowledgements

\section{Author's short biography}

Elena Korosteleva is Professor of International Politics and Jean Monnet Chair of European Politics, at the School of Politics and International Relations, University of Kent. She is a PI to a large GCRF COMPASS project (2017-21) to examine the concepts of governance, order, peoplehood and resilience as a selfgoverning project in the eastern region and Central Asia. Her wider research interests include the concepts of governance/governmentality; sustainability; democracy promotion and capacity-building. Most recent work include a contribution to a Special Issue 'Putting the EU Global Security Strategy to Test: 'Cooperative orders and Othering in EU-Russia Relations', International Politics 2018; Special Issue The Politics and The Political of the Eastern Partnership Initiative: re-shaping the agenda, East European Politics 33(3) September 2017; and 'The EU, Russia and the Eastern Region: the analytics of government for sustainable cohabitation', Cooperation and Conflict 51(3) 2016: 365-83.

\section{Postal Address:}

Professor Elena A. Korosteleva

School of Politics and IR

University of Kent

Canterbury CT2 7NX

UK 
Email: E.Korosteleva@kent.ac.uk

Phone: +441227823147 